\title{
Study of Ovarian Masses in Young Females: A Hospital Based Study
}

\author{
Paul BJ, Lamsal B, Sinha K, Das CR
}

\begin{abstract}
Objective: The purpose of this study was to analyze various clinical presentations, and the management of ovarian lesion in the young girls. Materials and methods: All the patients within the age limit of 20, who were admitted in the department of obstetrics and gynecology in NGMC between October 2011 to September 2015 with a diagnosis of an ovarian mass were analyzed. Age, presenting symptoms, duration of symptoms, physical examination findings and radiological imaging results were obtained. Ultrasonography was the gold standard for the diagnosis. The preliminary and final diagnoses were recorded. Results: 25 patients were identified, diagnosis of functional cyst was accounted for 9, 5 were hemorrhagic cyst and chocolate cyst and neoplastic tumors were accounted for 11 patients during the same period. The most common presenting complaint was abdominal pain. On physical examination 8 girls had abdominal tenderness and 15 patients had palpable masses. Conclusion Ovarian masses presenting with abdominal complaint can mimic other diseases. Ultrasound examination is one of the most important diagnostic tools. Preoperative diagnostic approach of the patient includes careful history taking, physical examination, imaging and evaluation of biological markers in selective cases. Conservative surgery is advocated to preserve the fertility potential of these patients.
\end{abstract}

Key words: Adolescent population, ovarian mass, west Nepal

\section{INTRODUCTION}

Ovarian tumors are uncommon but important childhood neoplasm. It is estimated that ovarian tumor makes up to $1.5 \%$ of all childhood malignancy. It represents the sixth most common female cancer and the 4" leading cause of death due to cancer in women².

Fortunately most ovarian masses in adolescents are benign: only $10 \%$ of the ovarian lesions in adolescent are malignant. The incidence of pediatric ovarian neoplasm is 2.6 per 100,000 girls. Approximately $2 \%$ of all ovarian cancers occur in female patients aged less than 25 years. The most common ovarian tumors in adolescence are germ cell tumors, accounting for $55 \%$ of ovarian tumors in this patient population. Malignant tumors are not associated with specific symptoms. On ultrasound, tumor masses with features such as multiloculations, papilloma, increased blood flow or solid elements may suggest malignant changes. Although most of the masses are benign but clinician should be aware of how they can present and should include ovarian masses in their differential diagnosis of lower abdominal pain, which is a common complication in this group of patient population.

In this study, our aim is to describe the spectrum of the adolescent and prepubertal ovarian pathology, identifying the
1. Dr. B. J. Paul
2. Dr. B. Lamsal
3. Dr. K. Sinha
4. Prof. C. R. Das

Address for correspondence:

Dr. B. J. Paul

Department of Obst. \& Gynae.

Nepalgunj Medical College Teaching Hospital,

Kohalpur, Banke, Nepal

Email: bhaskarjpaul@yahoo.co.in clinical features and ultrasound characteristics that help in decision making process about the patient management and to correlate this with histopathological result.

\section{MATERIALS AND METHOD}

This retrospective study was conducted at the gynecological units of Nepalgunj Medical College and Teaching Hospital from October 2011 to September 2015. Records of all cases of young patients, who were admitted with the diagnosis of ovarian mass, were retrieved from inpatients records and the operative registers. These cases were studied for age, presenting sign and symptoms, ultrasound reports, surgical procedure performed, staging of tumor in malignancy, sites of extra ovarian involvement and histopathological findings were documented and these data were collected on a proforma and analyzed. All cases with ovarian masses within the age limit of 20 years were included and patients with other pathology, like lower abdominal pain finally diagnosed as appendicitis were excluded.

\section{RESULTS}

There were 25 patients with detectable ovarian lesions who were managed during this period. The age of presentation ranged from 8 to 20 years, with $88 \%$ over 12 years of age. $32 \%$ of patients had physiological or functional ovarian cyst. The age of the patients were divided into 3 groups. 3 girls were between the age group of 8 to 12 years, 5 were between 13 to 15 years and rest of them (17) were between 16 to 20 years with a mean age of 16 years (15.96) (Table I).

In this cohort there were 4 girls (16\%) who did not start their menstruation. $21(84 \%)$ patients were menstruating on a variable interval (Table II). Out of 25 patients, 12(48\%) girls presented with palpable mass in the lower abdomen, $5(20 \%)$ presented with pain in the lower abdomen and $5(20 \%)$ 


\begin{tabular}{|c|c|c|}
\hline Age & $\mathbf{n}$ & (\%) \\
\hline $8-12$ & 3 & 12 \\
\hline $13-15$ & 5 & 20 \\
\hline $16-20$ & 17 & 68 \\
\hline
\end{tabular}

Table I: Age distribution $(n=25)$

\begin{tabular}{|c|c|c|}
\hline Status & $\mathbf{n}$ & (\%) \\
\hline Menstruating & 21 & 84 \\
\hline Premenstruating & 4 & 16 \\
\hline
\end{tabular}

Table II: Distribution of menstrual status $(n=25)$

presented with both palpable mass and pain abdomen. Out of 25 patients, 3 girls were admitted with the features of acute abdomen (torsion).

11 (44\%) patients had neoplastic lesion, palpable mass were felt in $9(81 \%)$ of them. $5(20 \%)$ patients presented with abdominal pain, $4(16 \%)$ presented with an asymptomatic mass (Table III). 8(32\%) patients underwent oophorectomy, 10(40\%) underwent cystectomy, 1 patient had mild peritoneal collection and none had pleural effusion.

\begin{tabular}{|l|c|c|}
\hline Chief complaint & $\mathbf{n}$ & $\mathbf{( \% )}$ \\
\hline $\begin{array}{l}\text { Palpable mass abdomen } \\
\text { with gradual swelling of the } \\
\text { abdomen }\end{array}$ & 12 & 48 \\
\hline Pain abdomen & 05 & 20 \\
\hline Mass+pain abdomen & 05 & 20 \\
\hline Associated problem & & \\
\hline Menstrual irregularity & 03 & 12 \\
\hline Dysmenorrhoea & 02 & 08 \\
\hline Urinary problem & 03 & 12 \\
\hline Acute abdomen & 03 & 12 \\
\hline Weight loss & 02 & 08 \\
\hline Precautious puberty & 00 & 00 \\
\hline Nausea vomiting & 02 & 08 \\
\hline General malaise & 03 & 12 \\
\hline Ascities/abdominal distension & 01 & 04 \\
\hline Incidental findings & 04 & 16 \\
\hline
\end{tabular}

Table III: Clinical presentation $(n=25)$

The histopathological diagnosis for epithelial tumor included 2 serous cyst adenoma, 1 mucinous cyst adenoma. 4(16\%) patients had bilateral ovarian lesion. Nobody underwent subsequent laparotomy for either staging or recurrence. 3 patients were referred out for further opinion for chemotherapy after obtaining histopathology report.

\begin{tabular}{|l|c|c|}
\hline Tumour Nature & $\mathbf{n}$ & (\%) \\
\hline Non Neoplastic variety & 14 & 56 \\
\hline Simple cyst & 9 & \\
\hline Hemorrhagic cyst & 4 & \\
\hline Chocolate cyst( Endometroid) & 1 & \\
\hline & & \\
\hline Neoplastic variety & 11 & 44 \\
\hline 1 Germ cell tumour & 7 & \\
\hline Matured teratoma & 5 & \\
\hline Immature teratoma & 1 & \\
\hline Dysgerminoma & 1 & \\
\hline 2. Epithelial tumor & 3 & \\
\hline Serous adenoma & 2 & \\
\hline Mucinous adenoma & 1 & \\
\hline $\begin{array}{l}\text { 3 Sex-chord tumour } \\
\text { (granulosa cell) }\end{array}$ & 1 & \\
\hline
\end{tabular}

Table IV: Histopathological diagnosis

Preoperative transabdominal ultrasonography was useful in identifying ovarian lesion. 15(60) patients show cystic masses whereas $7(28 \%)$ patients shows combined cystic and solid masses. 3 show features of suspected malignancy. 12 patients had palpable abdominal mass. So far treatment is offered, 8 patients underwent oophorectomy, 10 patients underwent cystectomy and 5 patients underwent unilateral salpingooophorectomy. While operating we found unilateral ovarian mass in 21 patients, bilateral lesion in 4 patients, endometrioma with chocolate cyst in 1 patient, lesion extending beyond pelvis in 5 patients, size of the lesion less than $8 \mathrm{~cm}$ in 7 patients and more than $8 \mathrm{~cm}$ in 18 patients. Out of 25 patients we could follow up 22 patients for subsequent 12 months, 3 patients were lost for follow-up and no patient reported for recurrence.

\begin{tabular}{|l|c|c|}
\hline Findings & $\mathbf{n}$ & (\%) \\
\hline Unilateral mass & 21 & 84 \\
\hline Bilateral mass & 04 & 16 \\
\hline Size of the mass $<8 \mathrm{~cm}$ & 07 & 28 \\
\hline Size of the mass $>8 \mathrm{~cm}$ & 18 & 72 \\
\hline $\begin{array}{l}\text { Endometrioma with } \\
\text { chocolate cyst }\end{array}$ & 01 & 04 \\
\hline Growth extending to pelvis & 05 & 20 \\
\hline Intraperitoneal invasion & 01 & 04 \\
\hline $\begin{array}{l}\text { Extension to abdomen \& } \\
\text { invasion }\end{array}$ & 01 & 04 \\
\hline Enlarged lymphnode $(>1 \mathrm{~cm})$ & 01 & 04 \\
\hline Ascitis & 00 & 00 \\
\hline
\end{tabular}

Table V: Peroperative Findings 


\begin{tabular}{|l|c|c|}
\hline Findings & $\mathbf{n}$ & (\%) \\
\hline Cystic & 13 & 52 \\
\hline Combined cystic \& solid & 09 & 36 \\
\hline Suspected malignancy & 03 & 12 \\
\hline
\end{tabular}

Table VI: Ultrasound Findings

\begin{tabular}{|l|c|c|}
\hline Type of Surgery & $\mathbf{n}$ & (\%) \\
\hline Diagnostic Laparoscopy & 00 & 00 \\
\hline $\begin{array}{l}\text { Diagnostic Laparoscopy } \\
\text { followed by laparotomy }\end{array}$ & 01 & 04 \\
\hline Ovarian resection & 00 & 00 \\
\hline Unilateral oophorectomy & 08 & 32 \\
\hline Unilateral cystectomy & 10 & 40 \\
\hline $\begin{array}{l}\text { Unilateral salpingo } \\
\text { oophorectomy }\end{array}$ & 05 & 20 \\
\hline Excisional biopsy & 00 & 00 \\
\hline Surgery on Bilateral ovary & 02 & 08 \\
\hline $2^{\text {nd }}$ look surgery & 00 & 00 \\
\hline
\end{tabular}

Table VII: Type of Surgery Done

\begin{tabular}{|c|c|c|c|}
\hline Age Group & \multicolumn{2}{|c|}{ Tumour Size } & $\%$ \\
\hline $10-12$ & 0 & 3 & 12 \\
\hline $13-15$ & 3 & 2 & 20 \\
\hline $16-20$ & 15 & 2 & 68 \\
\hline
\end{tabular}

$\mathrm{P}=0.01$ using chi square test

Table VIII: Age group and size of the tumour

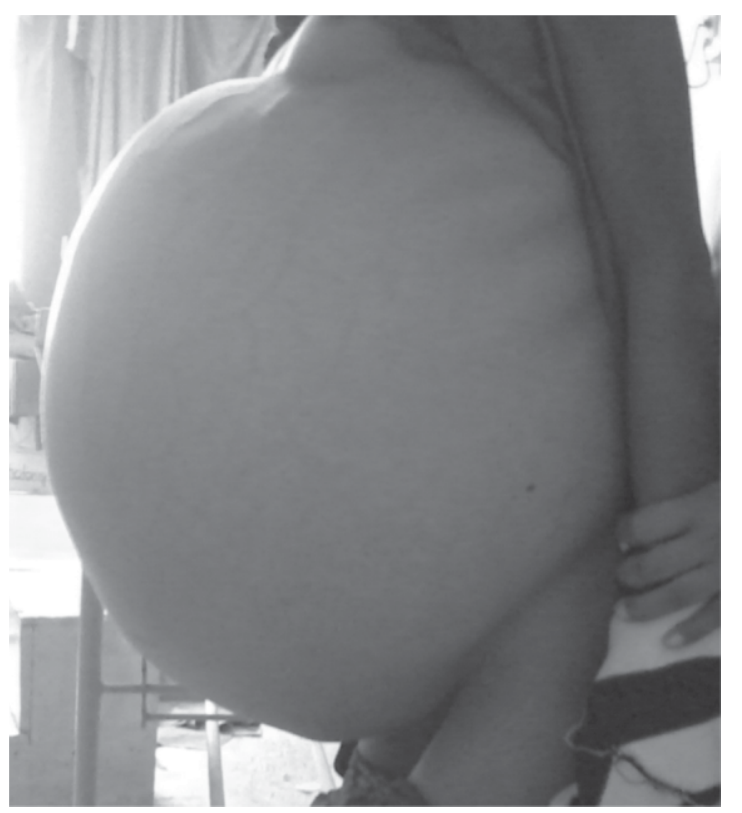

Figure 1: Huge serous cyst adenoma in a 18 years old girl : Lateral veiw

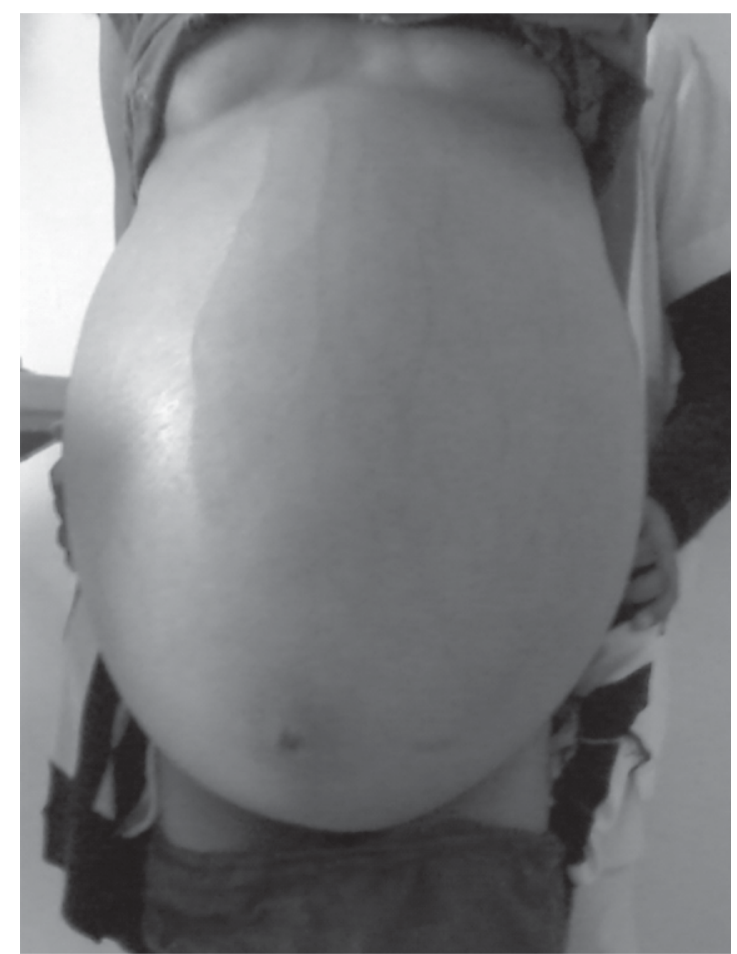

Figure 2: Serous cyst adenoma in a 18 years old girl : Front view

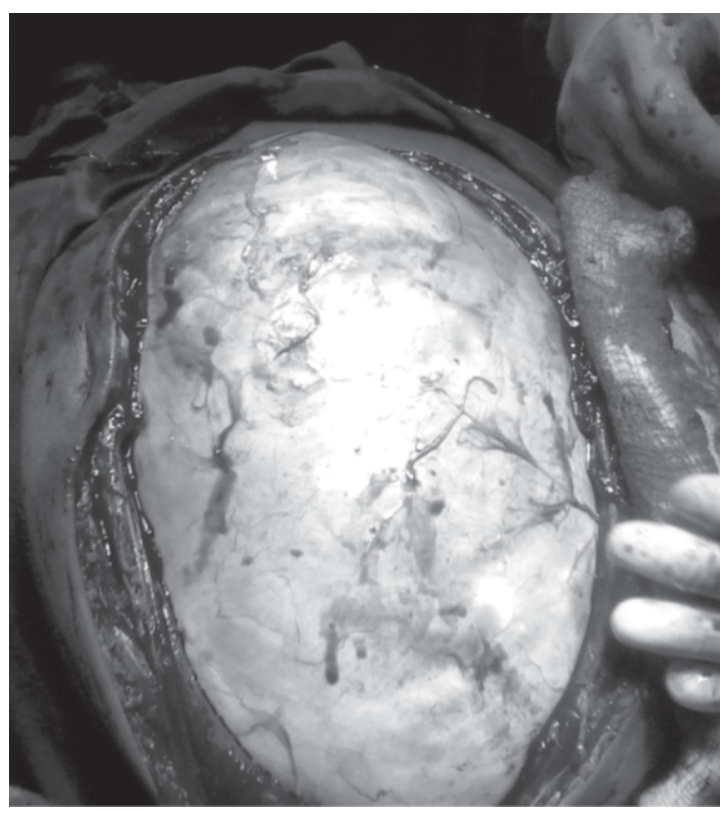

Figure 3: Same patient : size of the tumour : Pre-operative view

\section{DISCUSSION}

Most of the ovarian masses in our study group are benign (22 out of 25), there are 5 matured teratoma, 2 serous adenoma and 1 mucinous adenoma ( $88 \%$ benign variety) this was consistent with the study of Skinner et al. However Brown et al. 
reported that $33 \%$ of ovarian mass in patients between 8 to 18 years are malignant ${ }^{9}$. Symptoms and signs were varied and nonspecific. Based on this study the main complaint was gradual abdominal swelling with palpable abdominal mass for several months followed byAbdominal pain. 3 patients presented with menstrual irregularity. Parents should pay attention when their children have menstrual changes ${ }^{10}$.

Analysis of symptoms could not however help to distinguish between benign and neoplastic tumors. The most common mass was found to be simple cyst (9) followed by matured teratoma (5).

Ultrasonography has been found to be most helpful diagnostic tool for ovarian lesions. It was found to be almost 100 percent accurate in diagnosis of ovarian pathology however it lacks reliability between benign and malignant lesion in our series. Transvaginal sonography has been recommended as preferred means of diagnosis ${ }^{11}$. In our series of study, 56 percent mass was benign and 44 percent was neoplastic variety with 7 germ cell tumors, 3 epithelial tumor in relatively elderly group and one granulose cell tumor. The treatment of ovarian masses in children and adolescent group, was mostly conservative whether it is medical or surgical. In this study only 2 patients got bilateral ovarian surgery whereas most of the patients received unilateral cystectomy. $2^{\text {nd }}$ look surgery was not necessary and 3 patients were referred out for opinion regarding chemotherapy and there was no major post-operative complications. The treatment of anechoic cyst depends on the size at diagnosis. If they are symptomless, unilocular and less than $5 \mathrm{~cm}$. in diameter can be conservatively managed with regular follow up. Cysts larger than $5 \mathrm{~cm}$. often require surgery to avoid torsion, supported by Mayers et $\mathrm{al}^{12}$.

\section{CONCLUSION}

We are trying to present important descriptive data from a cohort of patients from western Nepal presenting in OPD of Teaching Hospital, NGMC. The incidence of ovarian tumor increases with age being common after 14 years. Gradual swelling of the abdomen associated with abdominal pain is the most common complaint in younger patients. The diagnostic standard for ovarian tumor is ultrasonography. Germ cell tumour was most common neoplastic presentation. Surgery is usually better for treatment and it is preferable to attempt conservative fertility sparing approach in adolescent patients.

\section{REFERENCES}

1. King DR. Ovarian cyst and tumours. in:Welch KJ, Randolph JG, Ravitch MM, editors.Pediatricsurgery. 4th ed. Chicago IL: Year book; 1986. p. 1341-52. In Brown MF, Hebra A, McGeehin K, Ross AJ . Ovarian masses in children, a review of 91 cases of malignant and benign masses. J PediatricsSurg 1993;28(7):930.

2. Tortolero-Luna G, Mitchell MF, Rhodes-Morris HE.Epidemiology and screening of ovarian cancer. ObstetGynaecolClin North Am 1994;21:63-75.

3. Day NE, Krishnan E. Epidemiology of gynaecological cancer. 2nd ed. Edinburgh: Churchill livingstone; 1997. p. 477-87. In Tariq S, Sohail R. Study of ovarian tumours in young girls. Professional Med J $2011 ; 18(1): 41-45$.

4. Al Jama FE, Al Ghamdi AA, Gasim T, Al Dakhiel SA, Rahman J, Rahman MS. Ovarian tumors in children and adolescence -a clinical study of 52 patients in a university hospital . J Pediatric AdolescenceGynaecol 2011;24(1):25.

5. Warner BW, Kuhn JC, Barr LL. Conservative management of large ovarian cysts in children; the value of serial pelvic ultrasonography. Surgery 1992;112(4):729-3-5.

6. Breen JL, Maxson WS.Ovarian tumours in children and adolescents.ClinObstetGynaecol 1977;20:607.

7. Norris HJ, Jensen RD. Relative frequency of ovarian neoplasm in children and adolescents. Cancer 1972;30(3):713.

8. Skinner MA, Schlatter MG, Heifetz SA, Grosfeld JL. Ovarian neoplasm in children. ArchSurg 1993;128:849-54.

9. Brown MF, Hebra A, McGeehin K, Ross AJ. Ovarian masses in children, a review of 91 cases of malignant and benign masses. J PediatricsSurg 1993;28(7):930.

10. Zhang M, Jiang W, Li G, Xu C. Ovarian masses in children and adolescent - an analysis of 521 clinical cases. J Pediatric Adolescent gynecol 2014;27(3):e73-7.

11. Sasaki H, Oda M, Ohmura M, Akiyama M, Liu C, Tsugane $\mathrm{S}$,etal.Follow up of women with simple ovarian cyst detected by transvaginal sonography in the Tokyo metropolition area. $\mathrm{Br} \mathrm{J}$ obstetGynaecol 1999;106(5):415-20.

12. Mayer C, Miller DM, Ehlen TG. Peritoneal implantation of squamous cell carcinoma following rupture of a dermoid cyst during laparoscopic removal.GynaecolOncol 2002;84(1):180-3. 